\title{
LETTER
}

\section{Two groups of fluid inclusions in the Yunotani eclogite from the Hida-Gaien Belt: Implications for changes of fluid salinity during exhumation}

\author{
Yuzuki ShinsI ${ }^{*}$, Tatsuki TsusImori ${ }^{* * *}$ and Tatsuhiko KaWAmoto ${ }^{* * *}$ \\ ${ }^{*}$ Department of Earth Science, Graduate School of Science, Tohoku University, Sendai 980-8578, Japan \\ ${ }^{* *}$ Center for Northeast Asian Studies, Tohoku University, Sendai 980-8576, Japan \\ ${ }^{* * *}$ Department of Geoscience, Shizuoka University, Shizuoka 422-8529, Japan
}

\begin{abstract}
Late Paleozoic Yunotani eclogites in the Itoigawa-Omi area of the Hida-Gaien Belt were subjected to a blueschist-facies recrystallization and deformation after the peak eclogite-facies metamorphism. We studied fluid inclusions in quartz domains of different metamorphic stages in the retrograde eclogite. Coarse-grained quartz filling pressure shadow of porphyroblastic garnets contains transgranular fluid inclusions (Group-I) with high salinity [6.0-8.0 eq mass $\% \mathrm{NaCl}$, with a mean value $7.2 \pm 0.6$ eq mass $\% \mathrm{NaCl}(n=12)]$. In contrast, transgranular fluid inclusions in later stage quartz-rich band (Group-II) in parallel to a penetrative foliation developed in matrix are characterized by lower salinity [1.1-5.8 eq mass $\% \mathrm{NaCl}$, with a mean value $3.4 \pm 1.2 \mathrm{eq}$ mass $\% \mathrm{NaCl}(n=12)]$. The occurrences of fluid inclusion trails suggest that each group corresponds to the fluids entrapped prior to the blueschist-facies recrystallization and the fluids entrapped during the blueschistfacies stage, respectively. The Group-II fluid inclusions formed at blueschist-facies conditions support the idea that aqueous fluids in the subduction channel have a salinity similar to seawater $(\sim 3.5$ eq mass\% $\mathrm{NaCl})$. Moreover, the Group-I fluid inclusions indicate a possibility that aqueous fluids at the eclogite-facies depth in subduction channels possess a salinity higher than seawater.
\end{abstract}

Keywords: Aqueous fluid inclusion, Retrograde eclogite, Blueschist-facies recrystallization, Itoigawa-Omi area, Hida-Gaien Belt

\section{INTRODUCTION}

Aqueous fluid inclusion is a minor but ubiquitous microscopic phase in various high-pressure and ultra-high pressure $[\mathrm{HP}(-\mathrm{UH} P)]$ metamorphic rocks. Since the minute aqueous fluid inclusions are trapped during and/ or after metamorphic crystal growth, a great attention has been focused on metamorphic fluids in subduction zone environment (e.g., Philippot et al., 1998; Scambelluri and Philippot, 2001; Frezzotti and Ferrando, 2015). Numerous fluid inclusion studies have found common occurrence of saline fluids (1-10 eq mass $\% \mathrm{NaCl})$ and even brines $(10-45$ eq mass\% $\% \mathrm{NaCl})$ in exhumed $\mathrm{H} P$-UHP rocks (e.g., Barr, 1990; Giaramita and Sorensen, 1994; Gao and Klemd, 2001; Sachan et al., 2017; Kawamoto

doi:10.2465/jmps.190729

Y. Shinji, yuzuki.shinji.r2@dc.tohoku.ac.jp Corresponding author T. Tsujimori, tatsukix@ tohoku.ac.jp et al., 2018; Brooks et al., 2019; Liu et al., 2019). The ubiquitous occurrence of fluid inclusions with high-salinity in subducted oceanic materials is critically important to evaluate fluid-mediated enhancement of various metamorphic reactions in subducting oceanic plates as well as fluid-mediated element cycling in solid Earth. Experimental studies have revealed that $\mathrm{H}_{2} \mathrm{O}-\mathrm{NaCl}$ solution controls the stability limit of some metamorphic minerals and element mobility (e.g., Manning, 2004; Tropper and Manning, 2004; Newton and Manning, 2006; Kawamoto et al., 2014). Although there is a significant range of salinity of fluid inclusions entrapped in $\mathrm{H} P$ rocks, Kawamoto et al. (2018) suggested that aqueous fluids in the subduction channel have a salinity similar to seawater $(\sim 3.5$ eq mass\% $\% \mathrm{NaCl})$. Brooks et al. (2019) proposed a model to form higher salinity fluids up to $\sim 35$ eq mass $\% \mathrm{NaCl}$ from primary fluid inclusions with $\sim 4.0$ eq mass $\% \mathrm{NaCl}$; they suggested fluid-rock interaction 
in a relatively closed system. On the other hand, there are many observations of different salinities among different occurrences of fluid inclusion clusters/trails in an identical specimen. For examples, primary fluid inclusions in eclogite-facies minerals have higher salinity than that of transgranular (or secondary) (Simmons and Richter, 1976; Kranz, 1983) fluid inclusions entrapped during retrograde metamorphism (e.g., Sachan et al., 2017; Liu et al., 2019). However, salinity systematics of subduction zone metamorphism is not well constrained yet. In order to better understand the systematics, we focused on transgranular fluid inclusions in two types of quartz domains formed at different metamorphic stages in a retrograde eclogite, which is an eclogite-facies rock suffered from retrograde metamorphism overprint (e.g., Zhang et al., 2003). As described below, we found two groups of fluid inclusions with different occurrences and salinities. In this paper, we present the first report of fluid compositions at different metamorphic stages in Japanese late Paleozoic eclogites with a so-called 'Franciscan-type' retrograde pressure-temperature $(P-T)$ trajectory, in which the rocks retrace the almost identical path during exhumation to the prograde burial $P-T$ path.

\section{GEOLOGIC SETTING}

The Hida-Gaien Belt of the Hokuriku Region is a tectonic mixture of various pre-Jurassic lithologic slices of the Oeyama, Renge, Akiyoshi, and Maizuru Belts that are widely developed in Southwest Japan. In this belt, the late Paleozoic high-pressure $(\mathrm{H} P)$ schists derived from the Renge Belt occur associated with jadeitite-bearing antigorite serpentinite (e.g., Tsujimori, 2017; Tsujimori and Harlow, 2017). The 'Renge Schists' record mainly greenschist- to amphibolite-facies metamorphism and locally preserve blueschist- to eclogite-facies metamorphism. In the Omi area, the $\mathrm{H} P$ schists are divided into two distinct groups: an 'Eclogitic' (EC) unit and a 'Noneclogitic' (non-EC) unit (Tsujimori, 2002; Tsujimori and Matsumoto, 2006; Yamada et al., 2019) (Fig. 1). The EC unit consists mainly of paragonite-bearing metasedimentary schists with mafic layers or blocks of epidote blueschist, garnet blueschist, and glaucophane-bearing eclogite, both of which commonly contain glaucophane and/or barroisite. Prograde-zoned porphyroblastic garnets of eclogites preserve mineral inclusions showing a prograde transition from epidote-blueschist- to eclogitefacies metamorphism (at $2.0-2.2 \mathrm{GPa}$ and $550-600{ }^{\circ} \mathrm{C}$, Tsujimori, 2002; Tsujimori and Matsumoto, 2006). The matrix of eclogite has been subjected to a blueschist-facies recrystallization and deformation after the peak eclogite-facies metamorphism. According to Tsujimori et al.

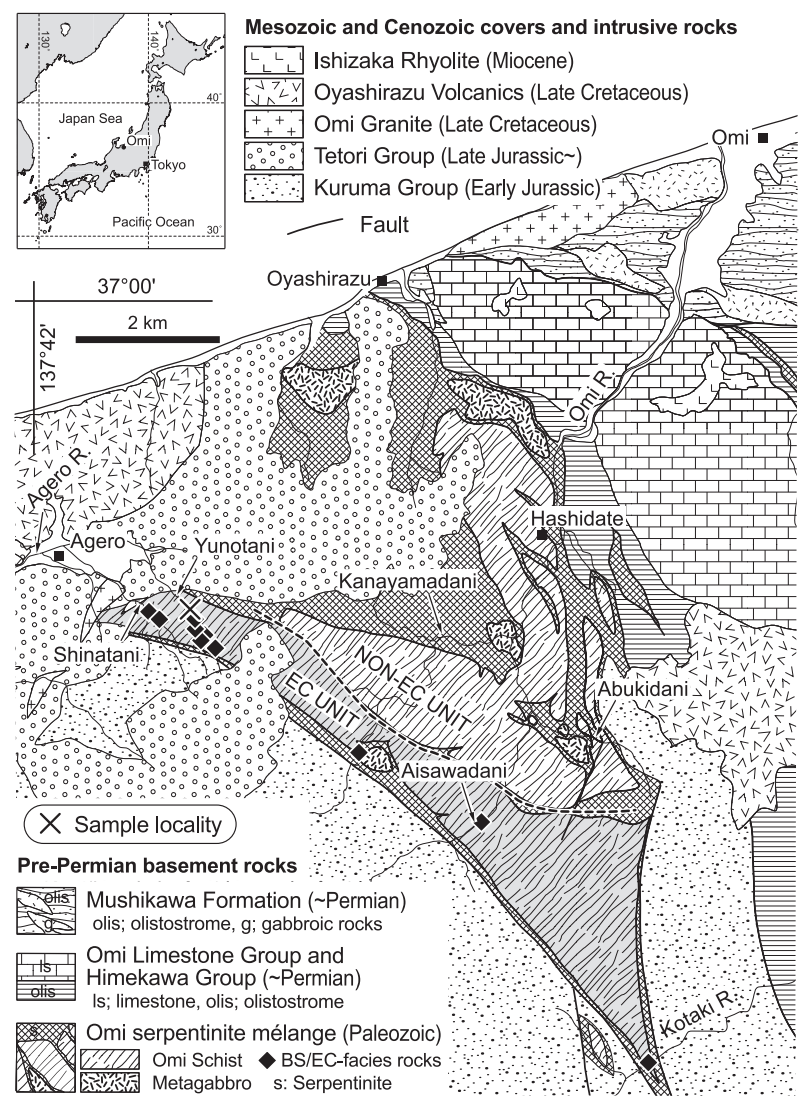

Figure 1. Geological map of the Itoigawa-Omi area, showing a sample locality (modified after Kumazaki and Kojima, 1996; Tsujimori, 2002).

(2000) and Tsujimori (2002), the matrix foliation $\left(S_{1}\right)$ is in parallel to an internal fabric (inclusion trail) of the peak eclogite-facies mineral assemblage in the garnet rims. However, the matrix omphacite is commonly replaced by chlorite, and initially coarse-grained glaucophane is reduced in grain-size. A pumpellyite-bearing retrograde blueschist-facies mineral assemblage is found in the garnet blueschist, an Mg-rich equivalent of the eclogite (Shinji and Tsujimori, 2019).

\section{SAMPLE DESCRIPTIONS}

We investigated fluid inclusions in retrograde eclogites found in the Yunotani Valley (Tsujimori et al., 2000; Tsujimori, 2002) (Fig. 1). The studied sample (YTECT02) is a well-foliated and retrograded eclogite, which characteristically contains quartz domains. The sample consists mainly of glaucophane, porphyroblastic garnet (up to $\sim 5$ $\mathrm{mm}$ in size), omphacite, epidote, quartz, rutile, and phengite. Titanite, chlorite, and rare albite occur as secondary minerals. A penetrative foliation $\left(S_{1}\right)$ is defined by a preferred orientation of neoblastic glaucophane in the matrix as well as inclusion fabrics of the mantle and rim portion 

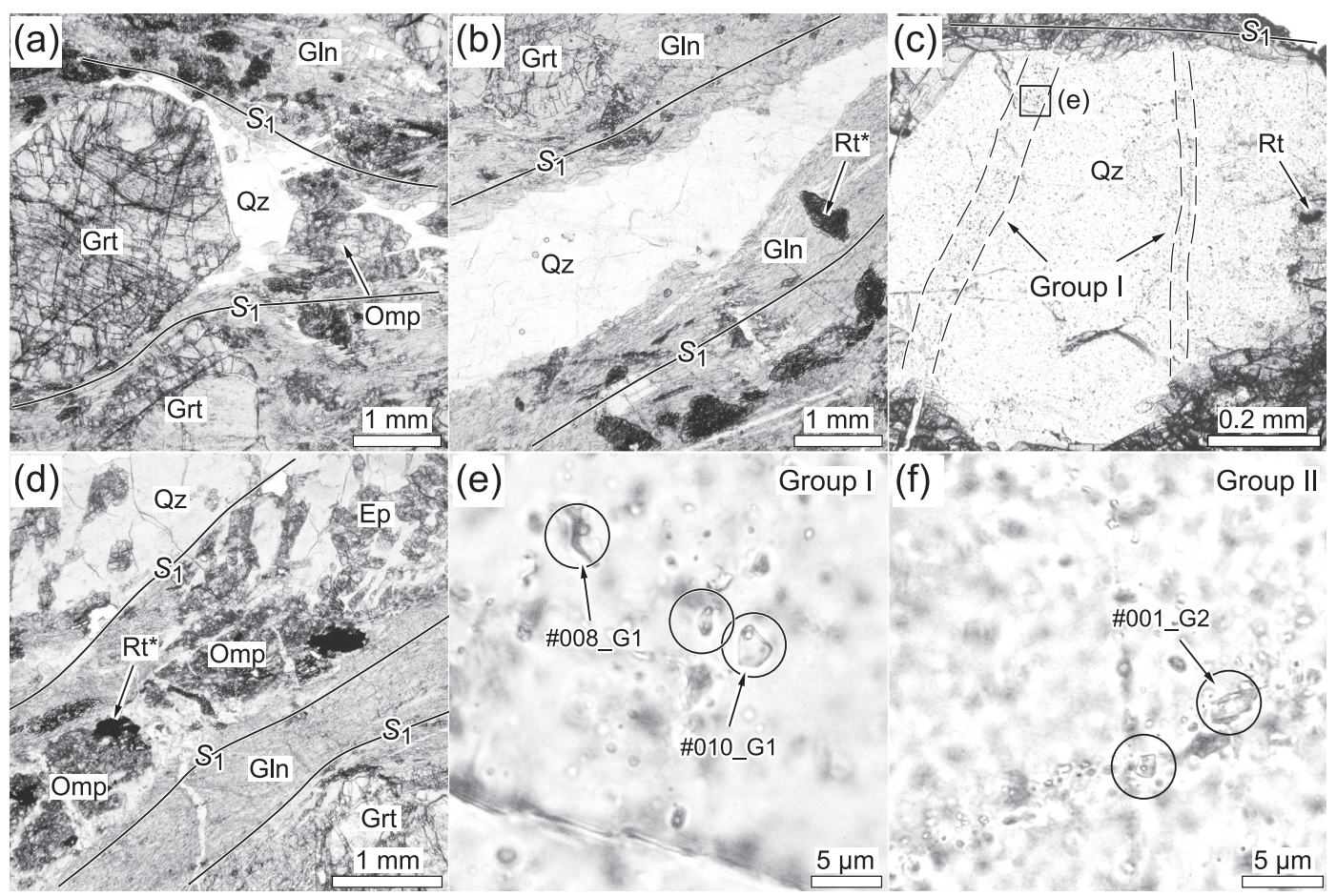

Figure 2. Photomicrographs showing the occurrences of the two types of quartz domains and the Group-I and -II fluid inclusions in the studied sample (YTECT02). (a) Coarse-grained quartz filling pressure shadow of porphyroblastic garnet and containing omphacite. (b) A welldeveloped quartz-rich band in parallel to the $S_{1}$ foliation. (c) Rutile without partial replacement by titanite and the Group-I fluid inclusions aligned at high angles to the $S_{1}$ foliation in a pressure shadow quartz domain. (d) Occurrence of the mineral assemblage glaucophane + epidote + titanite in the quartz-rich band. (e) Enlarged view of area shown as a rectangle in (c), showing the appearance of the Group-I fluid inclusions. Note that the analyzed fluid inclusion is labeled. (f) Inclusion trail of the Group-II fluid inclusions. Note that the analyzed fluid inclusion is labeled. Qz, quartz; Rt, rutile ( $\mathrm{Rt}^{*}$, rutile partially replaced by titanite); Grt, garnet; Gln, glaucophane; Ep, epidote.

of porphyroblastic garnets (Tsujimori, 2002). In the studied sample, two types of quartz domains occur: one is coarse-grained quartz filling pressure shadow of porphyroblastic garnets (Fig. 2a), the other is a quartz-rich band in parallel to the $S_{1}$ foliation (Fig. 2b). The presence of omphacite in some of the quartz domains at the pressure shadows suggests that the quartz domains were formed prior to the blueschist-facies recrystallization (Fig. 2a). In addition, the preservation of rutile without partial replacement by titanite suggests that the pressure shadow quartz domains were prevented from retrograde recrystallization and deformation (Fig. 2c). On the other hand, the mineral assemblage glaucophane + epidote + titanite in the quartz-rich band suggests that the crystallization (or recrystallization) of quartz in the band was postdated the peak of eclogite-facies metamorphism (Fig. 2d). Abundant fluid inclusion trails, normally $\sim 10-50 \mu \mathrm{m}$ wide in the thin section, occur in both types of quartz domains. The fluid inclusions are commonly two-phase (liquid + vapor), liquid-rich fluid inclusions with size variation from $\sim 1$ to $10 \mu \mathrm{m}$ in length and angular to rounded shape (Figs. 2e and 2f).

Based on the occurrences of fluid inclusion trails, we defined Group-I and -II fluid inclusions. The Group-I inclusions are transgranular inclusions, aligned at high angles to the $S_{1}$ foliation, and do not reach the boundary between the quartz domain and matrix (Fig. 2c). In contrast, the Group-II inclusions are also transgranular inclusions aligned along sealed microfractures but mostly in parallel to the $S_{1}$ foliation. Considering these, the Group-I and -II fluid inclusions were entrapped during the formation of the pressure shadow quartz domains and the quartz-rich band, respectively.

Phase identification of fluid inclusions was performed by HORIBA XploRA PLUS Confocal Raman Microscope at the Graduate School of Environmental Studies, Tohoku University. A $532 \mathrm{~nm}$ solid-state NdYAG laser with $10 \mathrm{~mW}$ power was used as the light source. The Raman spectra were measured ranging from 200 to $4400 \mathrm{~cm}^{-1}$ using a grating of $600 \mathrm{~g} / \mathrm{mm}$. The measuring area is $\sim 2 \mu \mathrm{m}$; the exposure time is $50 \mathrm{~s}(5 \mathrm{~s} \times 10)$. The Raman shift was calibrated using a reference silicon. All of analyzed fluid inclusions show room-temperature Raman spectrum with the $\mathrm{OH}$-stretching $\left(v_{\mathrm{OH}}\right)$ band at around $\sim 3200-3600 \mathrm{~cm}^{-1}$, indicating the presence of liquid $\mathrm{H}_{2} \mathrm{O}$ (Fig. 3). Any gas species were not detected. 


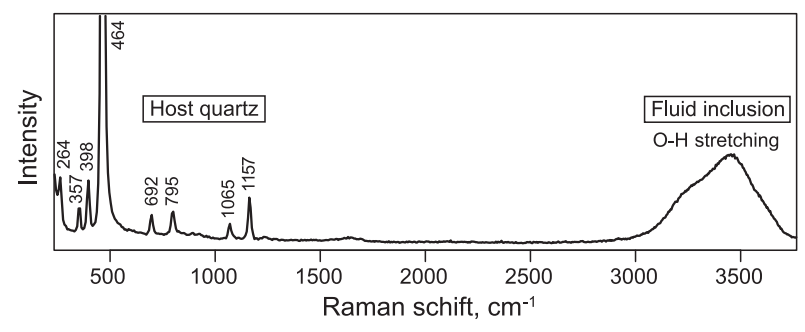

Figure 3. A representative Raman spectrum of fluid inclusions in the studied sample (FI/Qz-\#010_G1). Identification of the Raman peaks was carried out based on the Raman database of the RRUFF project (Lafuente et al., 2015) and Frezzotti et al. (2012).

\section{MICROTHERMOMETRY}

Doubly polished wafers with a thickness of about $40 \pm 15$ $\mu \mathrm{m}$ were prepared from the sample YTECT02 using a Metkon Forcipol 1V grinder/polisher, a Metkon Micracut 152 precision cutter and a Maruto Prepalap MG-300 polisher at Tohoku University. Then microthermometric measurements of fluid inclusions in one of the wafers (YTECT02 ts39) were performed on a Linkam Scientific THMS600 heating/cooling stage with $\times 100$ objective lens at Shizuoka University. Temperature was calibrated using synthetic fluid inclusion standards at $-56.6{ }^{\circ} \mathrm{C}$ (melting point of $\mathrm{CO}_{2}$ ), $0{ }^{\circ} \mathrm{C}$ (melting point of $\mathrm{H}_{2} \mathrm{O}$ ), and $373{ }^{\circ} \mathrm{C}$ (critical temperature of $\mathrm{H}_{2} \mathrm{O}$ ). $T_{\mathrm{h}}$ (homogenization temperature) and $T_{\mathrm{m}}$ (ice melting temperature) were determined at a heating rate of $0.5^{\circ} \mathrm{C} / \mathrm{min}$ and $0.2^{\circ} \mathrm{C} / \mathrm{min}$ at around $T_{\mathrm{h}}$ and $T_{\mathrm{m}}$, respectively. These rates were controlled with a constant heating rate of $0.1{ }^{\circ} \mathrm{C} / \mathrm{min}$ toward desired temperature. We estimated the salinity of $\mathrm{H}_{2} \mathrm{O}$ fluid inclusions using the relationship between salinity and freezing point depression (Bodnar, 1993). Precision of the $T_{\mathrm{h}}$ is within 1 ${ }^{\circ} \mathrm{C}$, and that of $T_{\mathrm{m}}$ is within $0.1{ }^{\circ} \mathrm{C}$, which results in estimated uncertainties of individual salinity measurements of $0.12-0.18$ eq mass $\% \mathrm{NaCl}$ in the range of 0 to $10 \mathrm{eq}$ mass\% $\mathrm{NaCl}$ (Bodnar, 1993).

The microthermometry results for all types of fluid inclusions are summarized in Table 1 and Figure 4a. The results are also plotted in a $T_{\mathrm{h}}-T_{\mathrm{m}}$ diagram (Fig. 5). The measured Group-I inclusions belong to a single trail, while those of the Group-II inclusions are located along several trails. All measured fluid inclusions show freezing between $\sim-38$ to $-51{ }^{\circ} \mathrm{C}$ characterized by sudden shrinkage of the vapor during cooling, and we observed first melting at $\sim-20{ }^{\circ} \mathrm{C}$ in one of the Group-I inclusions (FI/Qz-\#014 G1), indicating that $\mathrm{NaCl}$ or/and $\mathrm{KCl}$ present dominantly in the aqueous phase (Roedder, 1984). The salinity of the Group-I fluid inclusions ranges from 6.0 to 8.0 eq mass $\% \mathrm{NaCl}$, with a mean value $7.2 \pm 0.6$ eq $\operatorname{mass} \% \mathrm{NaCl}$ ( 1 s.d., $n=12$ ). In contrast, the Group-II
Table 1. Measured $T_{\mathrm{m}}$ and $T_{\mathrm{h}}$, and derived calculated salinity

\begin{tabular}{|c|c|c|c|}
\hline & $\begin{array}{l}\text { Derived salinity, } \\
\text { eq. } \text { mass } \% \mathrm{NaCl}\end{array}$ & $T_{\mathrm{m}},{ }^{\circ} \mathrm{C}$ & $T_{\mathrm{h}},{ }^{\circ} \mathrm{C}$ \\
\hline \multicolumn{4}{|l|}{ Group I } \\
\hline FI/Qz-\#005_G1 & 8.0 & -5.1 & 151 \\
\hline FI/Qz-\#006_G1 & 7.3 & -4.6 & 147 \\
\hline FI/Qz-\#007_G1 & 7.3 & -4.6 & 177 \\
\hline FI/Qz-\#008_G1 & 7.1 & -4.4 & 162 \\
\hline FI/Qz-\#010_G1 & 6.2 & -3.9 & 140 \\
\hline FI/Qz-\#012_G1 & 6.9 & -4.3 & 181 \\
\hline FI/Qz-\#013_G1 & 7.3 & -4.6 & 178 \\
\hline FI/Qz-\#014_G1 & 7.4 & -4.7 & 195 \\
\hline FI/Qz-\#015_G1 & 6.8 & -4.2 & 156 \\
\hline FI/Qz-\#020_G1 & 6.0 & -3.7 & 154 \\
\hline FI/Qz-\#022_G1 & 8.0 & -5.1 & 161 \\
\hline FI/Qz-\#044_G1 & 7.7 & -4.9 & $\mathrm{n} / \mathrm{a}$ \\
\hline Mean $(1 \sigma)$ & $7.2(0.6)$ & $-4.5(0.4)$ & $164(17)$ \\
\hline \multicolumn{4}{|l|}{ Group II } \\
\hline FI/Qz-\#001_G2 & 3.3 & -2.0 & $\mathrm{n} / \mathrm{a}$ \\
\hline FI/Qz-\#003_G2 & 2.6 & -1.5 & 136 \\
\hline FI/Qz-\#004_G2 & 3.9 & -2.3 & 137 \\
\hline FI/Qz-\#005_G2 & 4.5 & -2.7 & 160 \\
\hline FI/Qz-\#006_G2 & 4.7 & -2.8 & 141 \\
\hline FI/Qz-\#007_G2 & 5.8 & -3.6 & 162 \\
\hline FI/Qz-\#008_G2 & 3.2 & -1.9 & 147 \\
\hline FI/Qz-\#009_G2 & 3.6 & -2.2 & 154 \\
\hline FI/Qz-\#010_G2 & 1.1 & -0.6 & 149 \\
\hline FI/Qz-\#021_G2 & 2.6 & -1.5 & 161 \\
\hline FI/Qz-\#022_G2 & 2.9 & -1.7 & 141 \\
\hline FI/Qz-\#023_G2 & 3.0 & -1.8 & 167 \\
\hline Mean $(1 \sigma)$ & $3.4(1.2)$ & $-2.0(0.8)$ & $151(11)$ \\
\hline
\end{tabular}
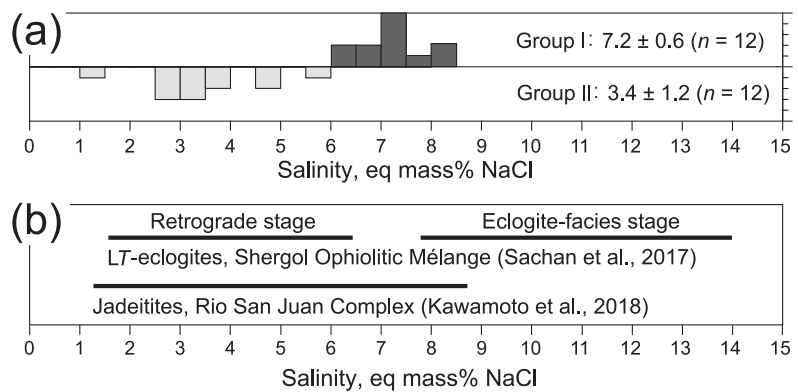

Figure 4. (a) Histograms showing the variation of salinity of the measured fluid inclusions. Numbers indicate mean values of salinity. (b) Variations of fluid inclusion salinities in rocks similar to the studied sample (Sachan et al., 2017) and Dominican-Republic jadeitites (Kawamoto et al., 2018).

fluid inclusions are characterized by lower salinity, ranging from 1.1 to 5.8 eq mass $\% \mathrm{NaCl}$, with a mean value $3.4 \pm 1.2$ eq $\operatorname{mass} \% \mathrm{NaCl}$ ( 1 s.d., $n=12)$.

$T_{\mathrm{h}}$ were measured together with $T_{\mathrm{m}} . T_{\mathrm{h}}$ for the GroupI fluid inclusions yield a range from 140 to $195^{\circ} \mathrm{C}$, with a 


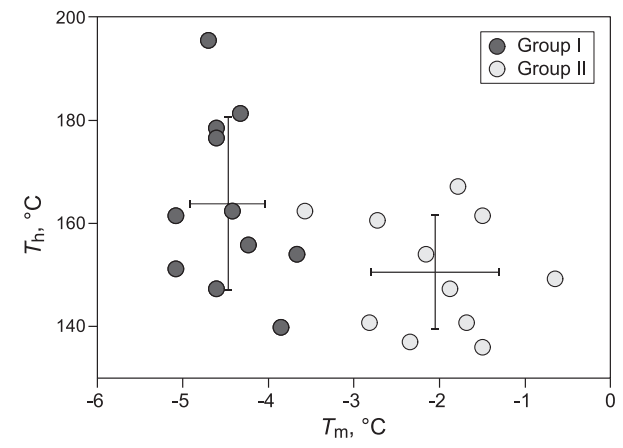

Figure 5. $T_{\mathrm{h}}-T_{\mathrm{m}}$ diagram showing the measured microthermometric data of the fluid inclusions. Mean values of $T_{\mathrm{h}}$ and $T_{\mathrm{m}}$ of each the fluid inclusion group are indicated, respectively; the error bars represent $1 \sigma$ standard deviation.

mean value of $164 \pm 17^{\circ} \mathrm{C}$ (1 s.d.). The $T_{\mathrm{h}}$ for the GroupII fluid inclusions yield a range from 136 to $167^{\circ} \mathrm{C}$, with a mean value of $151 \pm 11^{\circ} \mathrm{C}$ ( 1 s.d.). There is no obvious correlation between $T_{\mathrm{h}}$ and $T_{\mathrm{m}}$, i.e. salinity (Fig. 5). A large variation of $T_{\mathrm{h}}$ for the Group-I inclusions suggests that the Group-I inclusions suffered from various degrees of density $/ T_{\mathrm{h}}$ modification by stretching of fluid inclusion due to internal overpressure (e.g., Prezbindowski and Larese, 1987). However, the values of $T_{\mathrm{m}}$ have a small variation within the Group-I inclusions, and no texture indicating fluid leakage/refilling such as fractures and/or a secondary inclusion halo around an inclusion (Sterner and Bodnar, 1989) was observed, suggesting that the GroupI inclusions preserve the original fluid composition.

It is notable that our preliminary analysis of aqueous fluid inclusions in omphacite in the same sample (YTECT02_ts39) shows salinity lower (mean value of $2.6 \pm 0.7$ eq mass $\% \mathrm{NaCl}, n=10$ ) than the Group-I inclusions, although the timing of the entrapment remains unknown. The detail of the fluid inclusions in the omphacite will be described in the future.

\section{SIGNIFICANCE}

The Yunotani eclogite records a so-called 'Franciscantype' $P-T$ trajectory, in which the rocks retrace the almost identical path during exhumation to the prograde burial $P-T$ path (Tsujimori, 2002). Especially, the studied sample (YTECT02) suffered from intensive blueschist-facies recrystallization and deformation. As we reported above, we found two groups of fluid inclusions with different types of occurrence and salinities. The occurrence of the fluid inclusion trails suggests that each group corresponds to the fluids entrapped prior to the blueschist-facies recrystallization and the fluids entrapped during the blueschist-facies stage, respectively. Considering this, the observed difference of salinities would reflect difference of fluid compositions at different depths in a paleo-subduction zone. Based on the fluid inclusion study of jadeitites formed at blueschist-facies conditions, Kawamoto et al. (2018) suggest that aqueous fluids in the subduction channel have a salinity similar to or slightly higher than seawater $(\sim 3.5$ eq mass $\% \mathrm{NaCl})$ (Fig. $4 b)$. In our study, the Group-II fluid inclusions formed at a blueschist-facies condition support this idea. However, higher salinity in the Group-I fluid inclusions requires other explanation to have higher salinity.

There are a few reports of difference in fluid inclusion salinities among eclogite-facies condition and later retrograde conditions during exhumation in subduction setting (e.g., Sachan et al., 2017; Liu et al., 2019). Sachan et al. (2017) studied fluid inclusions in blueschist-facies retrograde eclogites in the Shergol Ophiolitic Mélange of Northwest India. They reported that eclogite-facies stage primary fluid inclusions in garnet and quartz included in garnet had higher salinity $(7.8-14$ eq mass $\% \mathrm{NaCl})$ than secondary fluid inclusions in quartz formed at blueschistfacies retrograde stage (1.7-6.4 eq mass \% NaCl) (Fig. 4b). The presence of omphacite in the pressure-shadow forming quartz domains in the studied sample suggests that the Group-I fluid inclusions were captured at near peak conditions prior to blueschist-facies condition. Considering our data of the Group-I fluid inclusions together with the case of the Shergol Ophiolitic Mélange, aqueous fluids at the eclogite-facies would be characterized by a salinity higher than seawater. For further understanding of the possible mechanism of the high salinity along the subduction channel, more systematic data focusing on fluid inclusions trapped during eclogite-facies metamorphism are required.

\section{ACKNOWLEDGEMENTS}

This research was supported by Tohoku University, Shizuoka University, and the University of Tokyo in part by MEXT/JSPS KAKENHI Grant Numbers JP15H05212 and JP18H01299, and the ERI JURP 2018-B-01 to T. Tsujimori, JP16H04075 and JP17H05314 to T. Kawamoto, and the Scholarship Grant for Graduate Students, Master 21 from the Yoshida Scholarship Foundation to Y. Shinji. We thank Noriyoshi Tsuchiya, Atsushi Okamoto and Masaoki Uno for use Raman facilities.

We extend our appreciation to Tomomi Hara for her assistance on Raman spectroscopy. We are grateful for constructive reviews from Kenta Yoshida and an anonymous reviewer.

\section{REFERENCES}

Barr, H. (1990) Preliminary fluid inclusion studies in a high-grade 
blueschist terrain, Syros, Greece. Mineralogical Magazine, 54, 159-168.

Bodnar, R.J. (1993) Revised equation and table for determining the freezing point depression of $\mathrm{H}_{2} \mathrm{O}-\mathrm{NaCl}$ solutions. Geochimica et Cosmochimica Acta, 57, 683-684.

Brooks, H.L., Dragovic, B., Lamadrid, H.M., Caddick, M.J. and Bodnar, R.J. (2019) Fluid capture during exhumation of subducted lithologies: A fluid inclusion study from Sifnos, Greece. Lithos, 332-333, 120-134.

Frezzotti, M.L., Tecce, F. and Casagli, A. (2012) Raman spectroscopy for fluid inclusion analysis. Journal of Geochemical Exploration, 112, 1-20.

Frezzotti, M.L. and Ferrando, S. (2015) The chemical behavior of fluids released during deep subduction based on fluid inclusions. American Mineralogist, 100, 352-377.

Gao, J. and Klemd, R. (2001) Primary fluids entrapped at blueschist to eclogite transition: evidence from the Tianshan metasubduction complex in northwestern China. Contributions to Mineralogy and Petrology, 142, 1-14.

Giaramita, M.J. and Sorensen, S.S. (1994) Primary fluids in lowtemperature eclogites: evidence from two subduction complexes (Dominican Republic, and California, USA). Contributions to Mineralogy and Petrology, 117, 279-292.

Kawamoto, T., Mibe, K., Bureau, H. and Reguer, S. et al. (2014) Large ion lithophile elements delivered by saline fluids to the sub-arc mantle. Earth, Planets and Space, 66, 61.

Kawamoto, T., Hertwig, A., Schertl, H.-P. and Maresch, W.V. (2018) Fluid inclusions in jadeitite and jadeite-rich rock from serpentinite mélanges in northern Hispaniola: Trapped ambient fluids in a cold subduction channel. Lithos, 308-309, $227-$ 241.

Kranz, R.L. (1983) Micro-cracks in rocks: a review. Tectonophysics, $100,449-480$.

Kumazaki, N. and Kojima, S. (1996) Depositional history and structural development of the Kuruma Group (lower Jurassic) on the basis of clastic rock composition. Journal of the Geological Society of Japan, 102, 285-302 (in Japanese with English abstract).

Lafuente, B., Downs, R.T., Yang, H. and Stone, N. (2015) The power of databases: the RRUFF project. In Highlights in Mineralogical Crystallography (Armbruster, T. and Danisi, R. M. Eds.). pp. 201, Walter de Gruyter GmbH, Berlin, 1-30.

Liu, H., Xiao, Y., van den Kerkhof, A. and Wang, Y. et al. (2019) Metamorphism and fluid evolution of the Sumdo eclogite, Tibet: Constraints from mineral chemistry, fluid inclusions and oxygen isotopes. Journal of Asian Earth Sciences, 172, 292307.

Manning, C.E. (2004) The chemistry of subduction-zone fluids. Earth and Planetary Science Letters, 223, 1-16.

Newton, R.C. and Manning, C.E. (2006) Solubilities of corundum, wollastonite and quartz in $\mathrm{H}_{2} \mathrm{O}-\mathrm{NaCl}$ solutions at $800{ }^{\circ} \mathrm{C}$ and 10 kbar: Interaction of simple minerals with brines at high pressure and temperature. Geochimica et Cosmochimica Acta, 70, 5571-5582.

Philippot, P., Agrinier, P. and Scambelluri, M. (1998) Chlorine cycling during subduction of altered oceanic crust. Earth and Planetary Science Letters, 161, 33-44.

Prezbindowski, D.R. and Larese, R.E. (1987) Experimental stretching of fluid inclusions in calcite - Implications for diagenetic studies. Geology, 15, 333-336.

Roedder, E. (1984) Fluid Inclusions. pp. 644, Reviews in Mineralogy, 12, Mineralogical Society of America.

Sachan, H.K., Kharya, A., Singh, P.C. and Rolfo, F. et al. (2017) A fluid inclusion study of blueschist-facies lithologies from the Indus suture zone, Ladakh (India): Implications for the exhumation of the subduction related Sapi-Shergol ophiolitic mélange. Journal of Asian Earth Sciences, 146, 185-195.

Scambelluri, M. and Philippot, P. (2001) Deep fluids in subduction zones. Lithos, 55, 213-227.

Shinji, Y. and Tsujimori, T. (2019) Retrograde pumpellyite in the Yunotani garnet blueschist of the Omi area, Japan: An update on the cooling path. Journal of Mineralogical and Petrological Sciences, 114, 26-32.

Simmons, G. and Richter, D. (1976) Micro-cracks in rock. In The Physics and Chemistry of Minerals and Rocks (Strens, R.G.J. Ed.). pp. 697, John Wiley-Interscience, London and New York, 105-137.

Sterner, S.M. and Bodnar, R.J. (1989) Synthetic fluid inclusions. VII. Reequilibration of fluid inclusions in quartz during laboratory simulated metamorphic burial and uplift. Journal of Metamorphic Geology, 7, 243-260.

Tropper, P. and Manning, C.E. (2004) Paragonite stability at $700^{\circ}$ $\mathrm{C}$ in the presence of $\mathrm{H}_{2} \mathrm{O}-\mathrm{NaCl}$ fluids: constraints on $\mathrm{H}_{2} \mathrm{O}$ activity and implications for high pressure metamorphism. Contributions to Mineralogy and Petrology, 147, 740-749.

Tsujimori, T. (2002) Prograde and retrograde P-T paths of the late Paleozoic glaucophane eclogite from the Renge metamorphic belt, Hida Mountains, southwestern Japan. International Geology Review, 44, 797-818.

Tsujimori, T. (2017) Early Paleozoic jadeitites in Japan: An overview. Journal of Mineralogical and Petrological Sciences, 112, 217-226.

Tsujimori, T., Ishiwatari, A. and Banno, S. (2000) Eclogitic glaucophane schist from the Yunotani valley in Omi Town, the Renge metamorphic belt, the Inner Zone of southwestern Japan. Journal of the Geological Society of Japan, 106, 353-362 (Japanese with English abstract).

Tsujimori, T. and Matsumoto, K. (2006) P-T pseudosection of a glaucophane-epidote eclogite from Omi serpentinite melange, SW Japan: A preliminary report. Journal of the Geological Society of Japan, 112, 407-414 (Japanese with English abstract).

Tsujimori, T. and Harlow, G.E. (2017) Jadeitite (jadeite jade) from Japan: History, characteristics, and perspectives. Journal of Mineralogical and Petrological Sciences, 112, 184-196.

Yamada, C., Tsujimori, T., Chang, Q. and Kimura, J.-I. (2019) Boron isotope compositions of antigorite-grade serpentinites in the Itoigawa-Omi area of the Hida-Gaien Belt, Japan. Journal of Mineralogical and Petrological Sciences, 114, 290-295.

Zhang, R.Y., Liou, J.G., Zheng, Y.F. and Fu, B. (2003) Transition of UHP eclogites to gneissic rocks of low-amphibolite facies during exhumation: evidence from the Dabie terrane, central China. Lithos, 70, 269-291.

Manuscript received July 29, 2019

Manuscript accepted December 8, 2019

Manuscript handled by Takayuki Sawaki 